\title{
Proximate Analysis of Aloe vara Leaves
}

\author{
M. Z. Haque *, M. B. Islam, M. A. Jalil and M. Z. Shafique \\ Drugs \& Toxins Research Division, BCSIR Laboratories, Rajshahi-6206, Bangladesh.
}

\begin{abstract}
Scientific investigations on Aloe vera have gained more attention over the last several decades due to its reputable medicinal properties. Aloe vera has a long history as a medicinal plant with diverse therapeutic applications. An experiment was conducted to evaluate the amount of dietary inclusion of Aloe vera leaves. Many of the health benefits associated with Aloe vera have been attributed due to the presence of protein, carbohydrate, fat etc. in the gel of the leaves. Proximate analysis of the leaves revealed fat, 1.83\%; protein, $10.50 \%$; ash, 19.50\%; carbohydrate, 56.27\%; phosphorous, $1.90 \mathrm{mg} / \mathrm{g}$ and energy, $290.08 \mathrm{kcal}$.
\end{abstract}

Keywords: Aloe vera, medicinal plant, proximate analysis, protein, dietary inclusion.

\section{Introduction}

The plant Aloe vera has a history dating back to biblical time which, belongs to the family liliaceae is a cactus-like perennial plant (Surjushe et al. 2008). This species is native to the Mediterranean region (or var.chinensis to India), but is now widely distributed in southern parts of North America, Europe, and Asia (Waller et al. 1978). Aloe vera leaves are formed by a thick epidermis (skin) covered with cuticle surrounding the mesophyll, which can be differentiated into chlorenchyma cells and thinner walled cells forming the parenchyma (fillet). The parenchyma cells contain a transparent mucilaginous jelly which is referred to as Aloe vera gel (Ramachandra and Rao, 2008). The genus Aloe contains over 400 different species with Aloe barbadensis Miller, is considered to be the most biologically active (Bozzi et al. 2007; Rajasekaran et al. 2005; Ritchie 2001; Moghaddasi and Verma 2011). The Aloe vera plant has been known and used for centuries for its health, beauty, medicinal and skin care properties. The name Aloe vera derives from the Arabic word "Alloeh" meaning "shining bitter substance," while "vera" in Latin means "true." 2000 years ago, the Greek scientists regarded Aloe vera as the universal panacea. The Egyptians called Aloe "the plant of immortality" (Rai et al. and Himesh et al. 2011). The plant is rich in many natural health promoting substances. The raw pulp of Aloe vera contains approximately $98.5 \%$ water, while the mucilage or gel consists of about $99.5 \%$ water (Eshun and $\mathrm{He}$, 2004). The remaining $0.5-1 \%$ solid material consists of a range of compounds including water-soluble and fat-soluble vitamins, minerals, enzymes, mono and polysaccharides, sugar, lignin, phenolic compounds and organic acids (Boudreau and Beland 2006; Lanjhiyana et al. 2011; Foster and Tyler's, 1999). The heterogeneous composition of the Aloe vera pulp may contribute to the diverse pharmacological and therapeutic activities which have been observed for aloe gel products (Talmadge 2004). Aloe vera is the most commercialized aloe species and processing of the leaf pulp has become a large worldwide industry. In the food industry, it has been used as a source of functional foods and as an ingredient in other food products, for the production of gelcontaining health drinks and beverages. In the cosmetic and toiletry industry, it has been used as base material for the production of powders, capsule, creams, lotions, soaps, shampoos, facial cleansers , oils and other products for both external and internal uses for a wide variety of indications (Hamman 2008; Haque et al. 2012). Aloes have long been recognized by pharmacopoeias over the world as a purgative drug; one variety, called Curacao aloes, is the dried juice of Aloe barbadensis (Osol 1973 and Rowson, 1967). The medicinal qualities of Aloe vera are much diversified and adoptogenic, such as would healing effect, reduces blood sugar in diabetes, sooths burns, eases intestinal problem, reduces arthritic swelling, ulcer curative object, stimulates immunes response against cancer etc (Ravi 2011). Aloe vera also provides antimicrobial (Campos et al. 2006; Yang et al. 2005), hypoglycemic effect (Hamman 2008), antioxidative ( $\mathrm{Li}$ et al. 2008), stimulates uterine contraction (Ritchie 2001) and anti-pruritic activities (Das 2011). The carbohydrates of Aloe juice have been reported to be glucose (Gjerstad 1971) and a polyuronide composed of (a) a polyose (molecular weight up to about $2.75 \times 10^{5}$ ) containing glucose and mannose and (b) hexuronic acids such as glucuronic, mannuronic, and galacturonic acids (Farkas 1963). A polysaccharide acemannan found in Aloe vera acts as an immune stimulant against psoriasis vulgaris (Paulsen et al. 2005).

Our previous research work (Haque et al. 2012) revealed that this miraculous plant also contains minerals like calcium (teeth and bone formation, muscle contractions and heart health), magnesium (strengthens teeth and bones, maintains healthy muscles and nervous system, activates enzymes), zinc (speeds up wound healing, mental quickness assists with healthy teeth, bones, skin, immune system, and digestive aid), manganese (activates enzymes, builds healthy bones, nerves and tissues), chromium (assists with protein metabolism and 
balancing of blood sugars), which all influence our brain performance (Nwaoguikpe et al. 2010). Additional minerals found in Aloe vera include copper (important for red blood cells, skin and hair pigment), iron (involved in oxygen transportation and making of hemoglobin in red blood cells), potassium (helps with fluid balance), phosphorus (helps build bones and teeth, assists with metabolism and body $\mathrm{pH}$ ), and sodium (regulates body liquids, helps with nerve and muscle performance, and helps deliver nutrients into body cells) (Barcroft and Alasdair, 1999).

\section{Collection of plant materials}

\section{Materials And Methods}

Aloe barbadensis plants for the present study were obtained from the experimental Aloe vera garden of BCSIR Laboratories, Rajshahi.

\section{Preparation of Aloe vera powder}

The collected Aloe vera leaves $(10 \mathrm{~kg})$ were cleaned and chopped into small pieces by a chopper. It was then dried in a solar drier for 16 hours. The dried mass was then crushed by a crushing machine and sieved (200 mesh). Finally, to it was added sodium meta bisulphite $(0.1 \%)$ with simultaneously triturating. Finally, the brownish product was the desired Aloe vera powder (yield $1.0 \mathrm{~kg}, 10 \%$ ). The physico-chemical properties of the product were analysed and the results are summarized in Table 1.

\section{Analysis of Proximate composition of Aloe leaves}

Proximate composition such as ash (minerals), fat and protein also known as Weende analysis is a chemical method of assessing and expressing the nutritional value of a feed, which reports the present in a fuel as a percentage of dry fuel weight. The proximate analyses gives the overall nutritional composition of the sample in question, this is briefly complemented by antinutrient and mineral composition of the sample.

\section{Determination of moisture}

Moisture content was determined by standard IUPAC method (1977). 2 gms of sample were weighed in a porcelain crucible (which was previously cleaned, heated to $105^{\circ} \mathrm{C}$ cooled and weighed). The crucible with the sample was heated in an electrical oven for about six hours at $105^{\circ} \mathrm{C}$. It was then cooled in desiccators and weighed again. The percentage moisture in the oil cakes was calculated from the formula:

Moisture $=100\left(\mathrm{~W}_{1}-\mathrm{W}_{2}\right) / \mathrm{W}_{2} \%$, where $\mathrm{W}_{1}=$ Original weight of the sample before drying; $\mathrm{W}_{2}=$ Weight of the sample after drying.

\section{Determination of ash}

Ash content in Aloe vera powder was determined as described by AOAC (1955). About 2 gms of Aloe vera powder sample were weighed in a porcelain crucible (which was previously cleaned, heated to about $100^{\circ} \mathrm{C}$, cooled and weighed). The crucible with its content was placed in a muffle furnace for about four hours at about $600^{\circ} \mathrm{C}$. It then cooled in a desecrator and weighed. To ensure completion of ashing, the crucible was again heated in the muffle furnace for half an hour, cooled and weighed again. This was repeated till two consecutive weights were the same and the ash was almost white in colour.

\section{Estimation of protein}

Protein in the sample was determined by Micro-Kjeldahl distillation method (AOAC 1990). The samples were digested by heating with concentrated sulphuric acid $\left(\mathrm{H}_{2} \mathrm{SO}_{4}\right)$ in the presence of digestion mixture, Potassium sulphate $\left(\mathrm{K}_{2} \mathrm{SO}_{4}\right)$ and copper sulphate $\left(\mathrm{CuSO}_{4}\right)$. The mixture was then made alkaline with $40 \%$ $\mathrm{NaOH}$. Ammonium sulphate thus formed, released ammonia which was collected in $4 \%$ boric acid solution and titrated against standard $\mathrm{HCl}$. The percent nitrogen content of the sample was calculated the formula given below. Total protein was calculated by multiplying the amount of percent nitrogen with appropriate factor (6.25).

$$
\begin{aligned}
& \% \mathrm{~N}=\frac{1.4 \mathrm{X}(\mathrm{mL} \mathrm{HCl}-\mathrm{mL} \text { blank }) \mathrm{X} \text { Conc. of } \mathrm{HCl}}{\text { Weight of sample }(\mathrm{g})} \\
& \% \text { Protein }=\% \mathrm{~N} \text { X Factor }(6.25)
\end{aligned}
$$

\section{Estimation of total carbohydrate}

Total carbohydrates were estimated following the anthrone method as described by Sadasivam and Manickam (2008). The Aloe vera powder sample $100 \mathrm{mg}$ were hydrolyzed with $5 \mathrm{ml}$ of $2.5 \mathrm{~N} \mathrm{HCl}$ in boiling 
water bath for 3 hours. The acid digested sample was cooled to room temperature and neutralized by adding sodium carbonate. The final volume is made to $100 \mathrm{ml}$ with distilled water and centrifuge at $5000 \mathrm{rpm}$ for 15 min. The supernatant was then collected and 0.5 and $1 \mathrm{ml}$ aliquots were taken for analysis of total carbohydrates. The green colour developed in reaction mixture was read at $630 \mathrm{~nm}$ using Spectronic-20 UVvisible spectrophotometer (Thermo Scientific, USA). D-glucose at the concentration of $100 \mu \mathrm{g} \mathrm{ml}^{-1}$ was used to prepare the standard curve. The amount of carbohydrate present is calculated by following formula.

Amount of carbohydrate present in $100 \mathrm{mg}$ of the sample= mg of glucose X 100

Volume of test sample

\section{Estimation of phosphorous}

Determination of Phosphorus from Aloe vera powder samples by following the method Vanadomolybdate yellow colour method was estimated (Bhargava and Raghupathi 2005). A 0.5gm of oven dried and grind sample less than 40 mesh $+7 \mathrm{ml}$ conc. nitric acid $+3 \mathrm{ml}$ perchloric acid in $30 \mathrm{ml}$ micro-Kjeldhal digestion flask. The sample was digested on digestion unit till the content becomes clear. The acid extract was diluted with distilled water in $100 \mathrm{ml}$ volumetric flask. The acid extract was used for phosphorus content of plant samples. $10 \mathrm{ml}$ aliquot of plant extract was pipetted out into $50 \mathrm{ml}$ volumetric flask. Then $10 \mathrm{ml}$ vanadomolybdate reagent was added, dilute to $50 \mathrm{ml}$ with DW, mix well and the intensity of the yellow colour was read at $470 \mathrm{~nm}$ on spectrometer. For the preparation of standard curve standard orthophosphate solution measuring $0,0.5,1.0,1.5,2.0$, and $2.5 \mathrm{ml}$ was taken separately in $50 \mathrm{ml}$ volumetric flask, and it was followed by the addition of $10 \mathrm{ml}$ of the ammonium molybdate-vanadate reagent. The content were diluted to $50 \mathrm{ml}$ with distilled water and mixed well. The absorbance was measured after $30 \mathrm{~min}$. at $470 \mathrm{~nm}$ on spectrophotometer and the graph was prepared. The amount of phosphorus was calculated from standard graph of phosphorous.

\section{Estimation of fat}

Fat determination is one of the key analyses used for food labelling and quality control. Fat content in the Aloe vera powder was determind by petoleum ether extraction followed by soxhelt apparatus (Jinadasa 2010). For the present study $5 \mathrm{~g}$ of finely ground sample was taken in a motor and anhydrous sodium sulphate of twice the weight of the sample was added into it. Then the mixture was ground until a free flowing powder was obtained. Then the powder was transferred to a thimble and sealed the end. Extraction thimble with the sample was placed in the soxhelt apparatus and fixed a previously dried and weighed round bottom flask. $200 \mathrm{~mL}$ of extracting solvent (petroleum ether) was added to the flask containing pumice chips. Then the Flask and the condenser were connected to the soxhelt extractor. Sample was allowed to reflux for about five hours. After the extraction flask was removed from the apparatus and kept in the water bath and then in the oven. Then the flask was cooled and weight was taken. Percent crude fat was calculated using the following formula.

$\%$ Crude fat $=\frac{(\mathrm{X}-\mathrm{E}) \mathrm{\times} 100}{\mathrm{~W}}$

Where, $\mathrm{X}-$ Weight of the flask with fat and chips, F - Weight of the flask and chips, W- Weight of the sample

\section{Results And Discution}

The results on identity, strength \& assay of Aloe vera powder and proximate composition are shown in Table 1 and 2 respectively. The carbohydrate content $(56.27 \%)$, which is the highest parameter, is a good source of carbohydrate provide readily accessible fuel for physical performance and regulate nerve tissue (Whimey and Rolfes 2005).

From Table 2 it is evident that ash content was the second highest parameter noted $19.50 \%$ in the present study. Ash content is a reflection of the mineral preserved in the sample represents the total mineral content, which are essential for the proper functioning of tissues and act as second messengers in some biological cascade mechanisms (Antia et al., 2006). Ash content may be important for several reasons as it is a part of proximate analysis for nutritional evaluation.

Protein which would be serve as enzymatic catalyst, mediate cellresponses, control growth and cell differentiation (Whimey and Rolfes 2005 ) was the third highest $(10.50 \%)$ parameter noted.

Moisture content determination is one of the most fundamental and important analytical procedure was observed $(6.75 \%)$

The lowest parameter noted was crude fat content $(1.83 \%)$, which are universally stored forms of energy in living organisms. They are major structural elements of biological membranes as phospholipids and sterols (Nelson and Cox 2008).

The mineral matter phosphorus that makes up $1 \%$ of a person's total body weight was found to be 1.90 $\mathrm{mg} / \mathrm{g}$ of Aloe vera powder. It is present in every cell of the body. Most of the phosphorus in the body is found in 
the bones and teeth. The main function of phosphorus is in the formation of bones and teeth. It plays an important role in how the body uses carbohydrates and fats. It is also needed for the body to make protein for the growth, maintenance, and repair of cells and tissues. Phosphorus also helps the body make ATP, a molecule the body uses to store energy. A standard curve of phosphorous is prepared and shown in Fig. 1. The concentration of phosphorous content in Aloe vera powder is calculated from the standard curve of phosphorous.

Table 1. Identity, strength \& assay of Aloe vera powder

\begin{tabular}{|l|c|}
\hline \multicolumn{1}{|c|}{ Constituents } & Amount \\
\hline Foreign organic matter: & Nil \\
\hline Purity: & $100 \%$ \\
\hline Moisture: & $6.75 \%$ \\
\hline Total ash: & $19.50 \%$ \\
\hline Water soluble ash: & $12.50 \%$ \\
\hline Acid insoluble ash: & $2.25 \%$ \\
\hline pH values (1\% solution): & 6.9 \\
\hline Solid content: & $68.50 \%$ \\
\hline
\end{tabular}

Table 2. Proximate composition of Aloe vera leaves.

\begin{tabular}{|c|c|c|}
\hline Sl. No. & Parameters & Percentage (\%) \\
\hline 1. & Ash & 19.50 \\
\hline 2. & Carbohydrate & 56.27 \\
\hline 3. & Protein & 10.50 \\
\hline 4. & Crude Fat & 1.83 \\
\hline 5. & Phosphorous & $1.90 \mathrm{mg} / \mathrm{g}$ \\
\hline
\end{tabular}

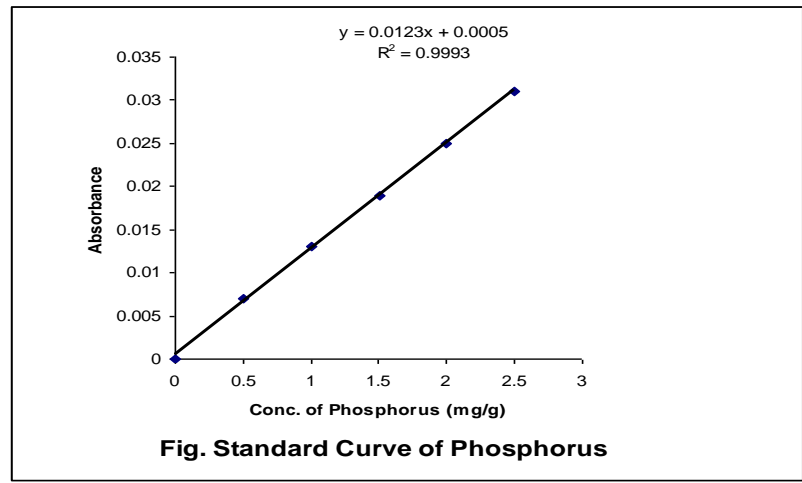

\section{Conclusion}

The miraculous medicinal plant Aloe vera has been proved to be a good source of protein, carbohydrate, fat and minerals. It could, therefore, be used as an important dietary source of nutrients in a food based approach for combating micronutrient deficiency.

\section{References}

[1]. Antia BS, Akpan PA, Okon, Umoren IU (2006) Nutritive and anti-nutritive evaluation of sweet potatoes (Ipomoea batatas) leaves, Pak.J.Nut.5,166-168.

[2]. AOAC (1990) Official Methods of Analysis: (15thedn), Association of Official Analytical Chemists, Washington, D.C

[3]. Barcroft, Alasdair (1999) Aloe Vera Healer, www.JoJaffa.com, http://www.AloeVeraHealer.com, Online: Chapter 4.

[4]. Bhargava BS, Raghupathi HB (2005) Methods of Analysis of soils, Plants, Waters, Fertilizers and Organic Manures; Second edn edited by Tondon HLS., Fertilizer Development and Consultation organization, New Delhi, 87-88.

[5]. Boudreau MD, Beland FA. (2006) An evaluation of the biological and toxicological properties of Aloe Barbadensis (Miller), Aloe vera, J. Environ. Sci. Health C, 24, 103-154.

[6]. Bozzi A, Perrin C, Austin S, Vera FA (2007) Quality and authenticity of commercial Aloe vera gel powders. Food Chem. 103(1), 22-30.

[7]. Campos M, Cordi L, Durán N, Mei L (2006) Antibacterial activity of chitosan solutions for wound dressing. Macromol Symposia, 1(5), 15-18

[8]. Das S (2011) Isolation and characterization of novel protein with anti-fungal and anti-inflammatory properties from Aloe vera leaf gel, Int. J Biol. Macromol, 48(1), 38-43.

[9]. Eshun, K, He Q (2004) Aloe vera: A valuable ingredient for the food, pharmaceutical and cosmetic industries, A review. Crit. Rev. Food Sci. Nutr, 44, 91-96.

[10]. Farkas A (1963) Topical medicament including polyuronide derived from Aloe, U. S. Patent, 3,103,466

[11]. Foster S. Tyler's (1999) Honest Herbal: A sensible guide to the use of herbs and related remedies, New York: Haworth Herbal Press.

[12]. Gjerstad G (1971) Adv. Front. Plant Sci, 28,311-315. 
[13]. Hamman JH (2008) Composition and Applications of Aloe vera Leaf Gel, Molecules, 13, 1599-1616; DOI: $10.3390 /$ molecules 13081599

[14]. Haque MZ, Rouf MA, Jalil MA, Islam MB, Islam MM, Ahsan MA (2012). Studies on The Production of Musabbar From Aloe Vera, Journal of Advanced Scientific Research, 3(1),51-54.

[15]. Himesh S, Sarvesh S, Kaushelendra M, Singhai AK, Neelesh C (2011) Qualitative and Quantitative Profile of Aloin Isolated from Aloe vera, JRJP, 2(9),121-122

[16]. IUPAC (1977) Standard Methods for the Analysis of Oils, Fats and Derivatives, 6th edition, Pergamon Press, Paris.

[17]. Jinadasa BKKK (2010) Determination of fat, GS/M.Sc/Food/3608/08.

[18]. Lanjhiyana S, Garabadu D, Ahirwar D, Bigoniya P, Rana AC, Patra KC, Lanjhiyana SK (2011) Karuppaih M. Antihyperglycemic potential of Aloe vera gel in experimental animal model. Ann Biol Res. 2(1), 17-31.

[19]. Li Z, Zhong H, Peng X, Li J, Zheng J (2008) Effect of chitosan and $\mathrm{CaCl}_{2}$ on senescence and membrane lipid peroxidation of postharvest kumquat fruits. Acta Horticulturae, 769, 259-64.

[20]. Moghaddasi SM, Verma SK (2011) Aloe vera their chemicals composition and applications: A review, Int J Biol Med Res.2(1), 466-471.

[21]. Nelson DI, Cox MM (2008) Lehninger Principles of Biochemistry, $5^{\text {th }}$ Edn W.H. Freeman and Company, Madison Avenue, New York, pp:343.

[22]. Nwaoguikpe RN, Braide W, Ezejiofor TIN (2010) The effect of Aloe vera plant (Aloe barbadensis) extracts on sickle cell blood (hbss), Afr. J. Food Sci. Technol, 1(3), 058-063.

[23]. Official and tentative Methods of Analysis of the Association of Official and Agricultural Chemists, $(1955), 8^{\text {th }}$ Ed. Washington, $: 468-470$.

[24]. Osol A, Pratt R, Gennaro AR (1973) The United States Dispensatory, J. B. Lippincott Co., Philadelphia, pp. 46-49.

[25]. Paulsen E, Korsholm L, Brandrup FA (2005) Double-blind, placebo-controlled study of a commercial Aloe vera gel in the treatment of slight to modérate psoriasis vulgaris. J Euro and Acad Dermatol and Venereol, 19(3),326-31.

[26]. Rai S, Sharma DK, Arora SS, Sharma M, Chopra AK (2011) Concentration of the heavy metals in Aloe vera L. (Aloe barbadensis Miller) Leaves collected from different geographical locations of India. Ann Biol Re. 2(6), 575-579.

[27]. Rajasekaran S , Sivagnanam K, Subramanian S (2005) Modulatory effects of Aloe vera leaf gel extract on oxidative stress in rats treated with streptozotocin, J Pharm and Pharmacol, 57(2), 241-246.

[28]. Ramachandra CT, Rao PS (2008) Processing of Aloe Vera Leaf Gel: A Review, Am. J. Agril. \& Biol. Sci. 3 (2), 502-510.

[29]. Ravi S, Kabilar P, Velmurugan S, Kumar RA, Gayathiri M (2011) Spectroscopy Studies on the Status of Aloin in Aloe vera and Commercial Samples, Journal of Experimental Sciences, 2(8), 10-13

[30]. Ritchie H E (2001) The safety of herbal medicine use during pregnancy, Frontiers in fetal health, 3(10), 259-266.

[31]. Rowson JM (1967). Analyst (London), 92, 593-596.

[32]. Sadasivam S, Manickam A (2008) Biochemical Methods, New Age International (P) Ltd., Publishers New Delhi, $3^{\text {rd }}$ Edition.

[33]. Surjushe A, Vasani R, Saple DG (2008). Aloe Vera: A Short Review, Indian J Dermatol, 53(4), 163-166. doi: 10.4103/00195154.44785

[34]. Talmadge J, Chavez J, Jacobs L, Munger C, Chinnah T, Chow JT, Williamson D, Yates K (2004) Fractionation of Aloe vera L. inner gel, purification and molecular profiling of activity. Int.Immunopharmacol, 4, 1757-1773.

[35]. Yang TC, Chou CC, Li CF (2005). Antibacterial activity of N-alkylated disaccharide chitosan derivatives. Int. J Food and Microbiol, 97(1), 237-45.

[36]. Waller GR(1978) Mangiafico S, Ritchey CR, A Chemical Investigation of Aloe Barbadensis Miller, Department of Biochemistry, Oklahoma Agricultural Experimental Station, Oklahoma State University, Stillwater, Oklahoma; 69-76.

[37]. Whimey EN, Rolfes SR (2005) Understanding Nutrition, 10 $10^{\text {th }}$ Edn. Thomson/Wadsworth Publishing Company, Belmont, C.A. pp:132-137. 